\title{
Analyzing Inventory Turnover Performance in Different Retailing Mode of Operations
}

\author{
Junaid Ali Khan \\ Shiming Deng \\ Huazhong University of Science and Technology, China
}

doi: 10.19044/esj.2016.v12n34p34 URL:http://dx.doi.org/10.19044/esj.2016.v12n34p34

\begin{abstract}
Inventory turnover differs across different retailers and operation modes employed by the retailers. Such a variation while undermining the usefulness of inventory turnover for performance analysis; requires particular attention. We perform an empirical analysis using sales data from a large retail firm for the year 2013-2016 for investigating the relationship of inventory turnover with mode of operations. The analysis reveals that the variation of inventory turnover among different mode of operations is much larger than variation of inventory turnover within each mode. So there is significant relationship between mode of operations and inventory turnover. This study inspects the influence of different channel structures on inventory turnover in a large supermarket, which has employed multiple modes of operations in different categories.
\end{abstract}

Keywords: Inventory turnover, modes of operation, retail

\section{Introduction}

Transfer of channel of power from manufacturers to retailors is actually a consequence of an advent of the dominant retailors. Traditionally retailers was buying the stock from multiple manufacturers and then sell them to customers as known as reseller mode. Retailer for a long time had been working only as an intermediary between producer and customer. Recently, manufacturers and retailers are forming new contractual relationships to minimize their risk and conflicts and increase the profit. Manufacturers are either renting space from the retailer to reach to customer directly or forming a revenue sharing partnership with the retailer. In this distribution mode the manufacturer pays the retailer a fraction of total sales revenue produced in the store or a fixed amount. It has gained prominence and popularity due to its significant potential for reducing channel conflict and can be beneficial for both retailer and the manufacturer. 
However, these channel structures have their own issues that can potentially come up. On one hand, due to dominant nature of retailer it can claim excessively high shares of sales revenue. On the other hand, a direct and fierce competition between manufacturers in the store can create an environment of intensive price competition lowering the retail prices eventually. Additionally, such a revenue sharing technique between the retailer and manufacturers can create distortions in non-price promotional and selling efforts from both parties. Li et al (2016) showed that average retail price is less and sale is higher in distribution mode compared to reseller mode for watch and cell phone category. Better understanding the consequences of these channel structures on other performance variables specially inventory turnover requires further firsthand investigation, which is the main objective of current study.

In this study we have used data from a Chinese supermarket, which sell products in different categories under different mode of operations. The undersigned objective of this paper is to analyze the inventory turnover in different modes of operation in China. Although confined to single retailer, this kind of empirical analysis on point of sale data enables us to directly test the impact of different mode of operations on managerial metrics. In our study we will focus on multiple categories belong to food and non-food section.

\section{Literature Review}

This research adds much to the operations and marketing literature on channel and inventory management. The literature currently available does not contain enough analysis of mode of operations other than distribution in retailing. To the best of our knowledge, Jia et al (2016) did first comprehensive study on the abovementioned topic that directly analyzes the consequences of distribution systems. After shifting to distribution the retail price on average is decreased and sale increased compared to reseller mode for cell phone and watch category.

The double marginalization issue is the commonly found and a familiar problem faced in channel coordination whereas retailers tend to charge higher retail prices as compared to the optimal price levels maximizing the total channel profits while doing so (Shepard 1993, Spengler 1950). Several theoretical studies have analyzed the question of using several transfer pricing structures or other formal agreements for improving coordination between channels (Cachon 2003), (Cachon and Lariviere 2005). Policies such as implicit understanding (Shugan 1985), formation of conjectures (Jeuland and Shugan 1988) and category captainship (Kurtulus et al. 2014, Subramanian et al. 2010) have also been studied. However, lack of sufficient data makes it hard to empirically test these models. 
While introducing competition between the supplier and the retailer, Arya et al. (2007) showed that encroachment by supplier can reduce double marginalization thus benefitting both sides given that the retailer must be more efficient in the retail process. Our study gives a comparison between the results when manufacturer sells through a retailer (reseller mode) and when they use retailer space to sell directly to the customer and share profit with retailer (distribution mode).

This study also contributes to the empirical research on channel management. Vertical relationship between retailers and manufacturers have been widely acknowledged and measured by researchers. Kadiyali et al. (2000) measured the power of channel members by analyzing channel profits that how are these divided. They found out that greater channel power results in greater share of the total channel profits. Sudhir (2001) studied competition among manufacturers vertical interactions with one retailer. These studies focus on the more traditional channel structure, that is, reseller. This study gives a comparison of reseller and distribution modes under different managerial metrics specifically inventory turnover, which hasn't been studied to the best of our knowledge.

Vendor-managed inventory (VMI) is one prominent and common system to facilitate channel coordination. In a VMI system, retailers assure the provision of access to their real-time inventory levels to the manufacturers and manufacturers decide inventory replenishments for themselves as they please (Aviv and Federgruen 2003, Mishra and Raghunathan 2004). Cachon and Fisher (1997) identified the aids of VMI for Campbell's but argued that such benefits can only be achieved through information sharing. Dong et al. (2014), however, showed that such a transfer of inventory decision making from the retailer to the manufacturer under VMI is helpful in significantly improving channel performance. Direct-Store-Delivery (DSD) is another method for facilitating channel coordination, whereas in this case upstream manufacturers are responsible to deliver the products to all retail stores, manage store shelf spaces and inventory along with the everything related to planning and executing the instore merchandising (Kurtulus and Savaskan 2013). Chen et al. (2008) used the cross-market data and empirically examined the economic efficiency of DSD systems through this cross-market data.

Distribution mode of retailer is same as VMI and DSD in a way that manufacturers also have acquired autonomy to control inventory and product delivery. In distribution mode, however, the retailer also gives various other decisions that are of pricing and promotion, to the manufacturers. This results in various other economic consequences which were not explored earlier in the empirical literature. For example, since manufacturers are capable of setting retail prices and managing product selling within stores, 
leading to an intense competition in pricing and service provision. In current study, Jerath and Zhang (2010) used a theoretical model for studying the store-within-a-store phenomenon, which is essentially the same as distribution mode. They have shown that the more competition decreases retail prices but manufacturers are still capable of enjoying higher profits. Consequently, gives manufacturers greater incentive for investing for the provision of better customer services. This study gives empirical tests for their analytical results. Furthermore, their model assumed that retailers always charge manufacturers an up-front fixed rent, which is not same as in the distribution mode under which retailers are capable of charging manufacturers a fraction of sales revenue. In another related study, Abhishek et al. (2015) theoretically examined the price implications when an online retailer decides to change from the traditional reselling arrangement (i.e., reseller) to agency selling (similar to distribution) in a multi-channel retailing environment (online and offline) where sales in one channel might have an effect on sales in another channel. Due to data limitations our study was only able to focus on a single channel.

This study also regards the growing body of empirical research in inventory management. In the recent years, several research papers in have addressed questions on performance and drivers of performance through analysis of firm-level inventories, industry-level inventories and other financial data in operations management.

Gaur et al. (2005) investigated the correlation of inventory turnover with gross margin, capital intensity and sales surprise by using the financial data for retail firms in a longitudinal study. They stated that changes in inventory turnover can be a consequence of product-portfolio changes, demand uncertainty, pricing and many other firm specific and environmental characteristics and we cannot interpret in terms of performance improvement or deterioration. They have also proposed a benchmarking methodology combining inventory turnover, gross margin, capital intensity and sales surprise for providing a metric of inventory productivity, which they have termed as adjusted inventory turnover.

Roumiantsev and Netessine (2007) tested some theoretical understandings from classical inventory models established at the SKU level by using the quarterly data from over 700 public US companies. They showed that inventory levels positively relate to demand uncertainty, gross margin and lead times in a longitudinal study by using the proxies for demand uncertainty and lead time. The authors also found evidence for economies of scale as most of the larger firms carry comparatively lower levels of inventory than most of the smaller firms.

Gaur et al (2007) has explained that changes in sales ratio, variables and firm size identified by GFR cause a significant proportion of the within- 
firm variation in inventory turnover. Particularly, inventory turnover of any firm has positive relationship with both its size and sales ratio.

Kolias et al (2011) has reached the same results as Gaur et al (2005) while he was analyzing the financial data of Greek retailers between 2000 and 2005. Gaur and Kesavan (2008) stretched the results of (Gaur et al., 2005) and also analyzed the relationship between inventory turnover with company's size and sales growth rate. They also proposed that inventory turnover has a positive correlation with both size and sales ratio.

This paper will analyze the effect of inventory turnover for different modes of operations in multiple categories employed in retailing. Our data is sourced from one of the largest supermarkets in China. We collected information on transaction-level sales, prices, inventory turnover days and other variables for a period of 41 calendar months. The forthcoming results in this study can also be applied in future research for assessment of the impact of improvements in operations on the inventory productivity of firms under different modes of operation.

\section{Data and Variable Description}

We use transaction sales data from one of the biggest Chinese retailer store chain in China Hubei Province. The data drawn from their internal database comprise of 41 months. It includes the information about sales of products belonging to 27 different products categories (food and non food) and store containing over 20,000 products at a time. This retail store has employed three modes of operation in their business i.e. Distribution, Reseller and Joint Venture to sell their products. As this firm has recently used Joint venture so not enough products are used in this mode so for this study we will only focus on two modes (Distribution \& Reseller).

Our original food section dataset contains around 350,000 observations in 15 categories and non-food section almost 400,000 in 12 categories spanning over 41 months. After initial exploratory analysis missing observations were removed. For the purpose of this study we only selected those categories that were contributing more to the revenue generation. Within each category we also excluded those products/brands from our dataset, which were not available in our store for more than 6 months during period of 2013-2016. We compared the pricing and inventory turnover of selected products with the overall category and found out no change which can be considered significant. Therefore we assess that the omission of rest of the products/brands should not have a substantial effect on the empirical results.

Our final food section dataset contains almost 162,000 observations in 7 categories and non-food section around 124,000 in 4 categories. Tables below present summary statistics of our final dataset. 
Table 1

\begin{tabular}{cc}
\hline Non-food Categories & Share of revenue (\%) \\
\hline Cosmetic and washing products & 58.15 \\
Textile & 16.19 \\
Tissue paper & 19.16 \\
Home appliance & 0.19 \\
Baby category & 6.31 \\
\hline
\end{tabular}

Table 2

\begin{tabular}{|cc}
\hline Food Categories & Share of revenue (\%) \\
\hline Fruits and Vegetables & 3.09 \\
Livestock & 9.17 \\
Fisheries & 0.14 \\
Food & 0.33 \\
\hline Daily use food & 17.28 \\
Grains and oil & 23.55 \\
Seasonings & 4.65 \\
Canned food & 0.73 \\
\hline Tobacco \& Alcohol & 16.15 \\
Candy \& Cookies & 8.82 \\
Snacks & 3.16 \\
\hline Beverages & 12.93 \\
\hline
\end{tabular}

Summary of some of the important variables is shown below.

\begin{tabular}{ccccccc}
\hline Section & $\begin{array}{c}\text { Retail Price } \\
\text { (RMB) }\end{array}$ & \multicolumn{2}{c}{$\begin{array}{c}\text { Tnentory Turn } \\
\text { Over } \\
\text { (Per month) }\end{array}$} & $\begin{array}{c}\text { Mode of Operations } \\
\text { (\# of Products) }\end{array}$ \\
\hline Food Category & Mean & SD & Mean & SD & Distribution & Reseller \\
\hline Livestock & 20.5 & 14 & 2 & 3.9 & 150 & 18 \\
Daily Use Food & 11.5 & 11.4 & 2.5 & 3.9 & 1204 & 42 \\
Grains \& Oil & 20.7 & 28.5 & 1.2 & 2.1 & 734 & 387 \\
Seasoning & 8.6 & 9.8 & 0.8 & 1.5 & 894 & 759 \\
Tobacco \& Alcohol & 55.7 & 94.7 & 1.1 & 1.9 & 269 & 370 \\
Candy \& Cookies & 11 & 13.9 & 0.9 & 1.5 & 1166 & 412 \\
Beverages & 37.1 & 61.4 & 1 & 1.8 & 963 & 583 \\
\hline
\end{tabular}

Table 4

\begin{tabular}{ccccccc}
\hline Section & $\begin{array}{c}\text { Retail Price } \\
\text { (RMB) }\end{array}$ & \multicolumn{2}{c}{$\begin{array}{c}\text { Inventory Turn } \\
\text { Over } \\
\text { (Per month) }\end{array}$} & \multicolumn{2}{c}{$\begin{array}{c}\text { Mode of Operations } \\
\text { (\# of Products) }\end{array}$} \\
\hline Non-food Category & Mean & SD & Mean & SD & Distribution & Reseller \\
Washing Products & 21.2 & 20 & 0.83 & 1.52 & 2372 & 2039 \\
Textile Products & 29.7 & 46 & 0.68 & 1.07 & 680 & 1486 \\
Tissues Products & 9 & 6.1 & 0.79 & 1.57 & 626 & 140 \\
Baby Products & 23.8 & 21.7 & 0.82 & 1.31 & 223 & 706 \\
\hline
\end{tabular}


The inventory turnover (ITO) specifies the frequency of turnover, sale and reproduction of inventories over the period being observed (Krasulja \& Ivanisevic, 2005). ITO in most of the retail companies, is the relative ratio of the purchase price, i.e. cost of goods sold (CGS) to the average amount of inventories over a given period of observation which is one year in most of the cases but in our study its one month, which gives better estimate of average amount of inventories.

\section{Research Hypothesis \& Model Specification}

In this section of article we prepare the hypotheses to relate mode of operations with Inventory turnover, Price and Category. A significant characteristic of our model is our focal attention over category-by-category variations in different modes than the variations within retailer as whole. This is done because each category has their own range in price, inventory turnover and other performance variables. For example prices in daily food category will be lower than the prices of products in cosmetics.

\section{HYPOTHESIS 1:Inventory turnover is higher in distribution than reseller mode}

Motivation for this hypothesis comes from the literature as shown by Gaur et al (2004) Increase in price decrease inventory turnover. While Price decreases in distribution mode compared to reseller mode (Jia et al 2016). So Inventory turnover should be higher in distribution mode. Dong et al. (2014) also showed that channel performance improves when inventory decision-making is transferred from the retailer to the manufacturer.

\section{HYPOTHESIS 2: Prices are lower in distribution mode.}

As Jia et al(2016) showed that prices decrease for watch and phone category in Distribution mode because of competition between manufacturers. But retail price can also increase under distribution mode because of negotiation between retailer and supplier, which can result in retailers claiming high share of sale revenue so manufacturers have to increase price to optimize channel profit. So due to such conflicting forces, it is never clear if the prices will decrease in distribution mode for every kind of products or in certain categories because of high share by retailer, price can increase.

To test our hypothesis we propose logistic regression model for finding effect of Inventory turnover (ITO) and Price on Mode of operations (MO).

$$
\operatorname{logit}\left(M O_{i}\right)=\beta_{0}+\beta_{1} \text { ITO }_{i}+\beta_{2} \text { Price }_{i}
$$

where indexes " $i$ " refer to time (month). $\beta_{1}$ and $\beta_{2}$ represents the coefficient to Inventory turnover and Price respectively. 


\section{Results}

Table.5 below shows logistic regression model for food and non-food section. Food section model proves our hypothesis 1 that inventory turnover is higher in Distribution mode compared to reseller mode. As for non-food section it looks like that high inventory turnover is associated with Reseller mode. Upon close examination of these two sections category-by-category we found that it's the Cosmetic \& Washing product category, which exhibits higher ITO for Reseller mode. Other three categories in non-food section support our Hypothesis 1. As for food section five out of seven categories support our Hypothesis 1. One possible reason for Cosmetics and Washing products having higher ITO in reseller mode can be that most of the brands are foreign (Lux, Walch, L'Oreal, Colgate) and they operate under distribution mode. Thus, the manufacturers may care more about maintaining the brand image and equity and therefore will be apprehensive towards engaging themselves in promotions prices with under Distribution mode. So higher prices for these foreign brands result in slightly lower ITO. This outcome is actually more consistent with the industry evidence (O'Connell and Dodes 2009, Dodes and Passariello 2011). Figure 1 below shows that actually there is not much difference between ITO over time for distribution and reseller mode in Cosmetics and Washing products category.

Hypothesis 2 is supported by both Food and Non-food section in table 5. Overall lower prices are associated with distribution mode. In category-by-category analysis we found that some categories despite having higher ITO in Distribution mode also have higher prices in that mode. It can be because of price insensitivity for certain kind of products. Even if price is high, customer will prefer to buy those products because of the image of brand as high quality such as in case of baby products. 
Table 5

\begin{tabular}{|c|c|c|}
\hline & \multicolumn{2}{|c|}{ Dependent variable: } \\
\hline & Food Section & Non-food Section \\
\hline \multirow[t]{2}{*}{ ITO } & -0.145 & $\underset{*}{0.007}$ \\
\hline & $(0.004)$ & $(0.004)$ \\
\hline \multirow[t]{2}{*}{ Price } & 0.004 & 0.007 \\
\hline & $(0.0001)$ & $(0.0003)$ \\
\hline \multirow[t]{2}{*}{ Constant } & -0.708 & -0.011 \\
\hline & $(0.007)$ & $(0.009)$ \\
\hline Observations & 161,882 & 123,846 \\
\hline Log Likelihood & $-99,027$ & $-85,088$ \\
\hline Akaike Inf. Crit. & $198,060.7$ & 170,182 \\
\hline Note: & \multicolumn{2}{|c|}{${ }^{*} \mathrm{p}<0.1 ;{ }^{* *} \mathrm{p}<0.05 ;{ }^{* * *} \mathrm{p}<0.01$} \\
\hline
\end{tabular}

Table 6

Non-Food Section

Dependent variable:

Mode of Operations (MO) (Reference Level: Distribution) Baby Products $\quad$ Cosmetics \&
Washing Textile Tissues

\begin{tabular}{|c|c|c|c|c|}
\hline \multirow[t]{2}{*}{ ITO } & -0.031 & 0.038 & -0.060 & -0.053 \\
\hline & $(0.016)$ & $(0.005)$ & $(0.013)$ & $(0.021)$ \\
\hline \multirow[t]{2}{*}{ Price } & -0.030 & 0.015 & -0.004 & 0.049 \\
\hline & $(0.001)$ & $(0.0004)$ & $(0.0003)$ & $(0.004)$ \\
\hline \multirow[t]{2}{*}{ Constant } & 2.206 & -0.334 & 1.060 & -2.225 \\
\hline & $(0.039)$ & $(0.012)$ & $(0.020)$ & $(0.049)$ \\
\hline Observations & 13,773 & 76,207 & 21,740 & 12,082 \\
\hline Log Likelihood & $-6,399.2$ & $-52,114.7$ & $-12,983$ & $-4,872$ \\
\hline Akaike Inf. Crit. & $12,804.4$ & $104,235.4$ & 25,972 & 9,750 \\
\hline Note: & & ${ }^{*} \mathrm{p}<0.1$ & ${ }^{* * *} \mathrm{p}<0.01$ & \\
\hline
\end{tabular}


Table 7

Food Section

Dependent variable:

\begin{tabular}{|c|c|c|c|c|c|c|c|}
\hline & & Mode of & Pperations ( & O) (Refer & ce Level: I & stribution) & \\
\hline & Candy & Daily & Beverages & Grains & Livestock & Seasoning & Tobacco \\
\hline & $\begin{array}{c}\& \\
\text { Cookies }\end{array}$ & $\begin{array}{l}\text { Use } \\
\text { Food }\end{array}$ & & \& Oils & & & $\begin{array}{c}\& \\
\text { Alcohol }\end{array}$ \\
\hline ITO & 0.027 & -0.182 & -0.060 & 0.007 & -0.099 & -0.100 & -0.143 \\
\hline & (0.008) & $(0.025)$ & (0.008) & $(0.006)$ & $(0.033)$ & (0.009) & $(0.013)$ \\
\hline Price & -0.015 & 0.055 & 0.002 & -0.011 & -0.018 & 0.036 & 0.002 \\
\hline & $(0.001)$ & $(0.002)$ & $(0.0002)$ & $(0.001)$ & $(0.006)$ & (0.002) & (0.0003) \\
\hline Constant & -1.007 & -4.253 & -0.613 & -0.376 & -2.023 & -0.284 & 0.409 \\
\hline & (0.019) & $(0.067)$ & (0.017) & $(0.019)$ & $(0.136)$ & (0.018) & $(0.027)$ \\
\hline Observations & 33,311 & 28,656 & 29,006 & 23,063 & 3,169 & 33,464 & 11,213 \\
\hline $\log$ & - & $-3,001.5$ & $-18,817.5$ & - & -830.5 & $-22,730$ & $-7,429.7$ \\
\hline Likelihood & $18,387.7$ & & & $14,859.6$ & & & \\
\hline AIC & $36,781.5$ & 6,009 & $37,641.1$ & $29,725.2$ & $1,667.1$ & 45,466 & $14,865.4$ \\
\hline Note: & & & ${ }^{*} \mathrm{p}<0$ & $\mathrm{p}<0.0$ & $\mathrm{p}<0.01$ & & \\
\hline
\end{tabular}

Figure 1

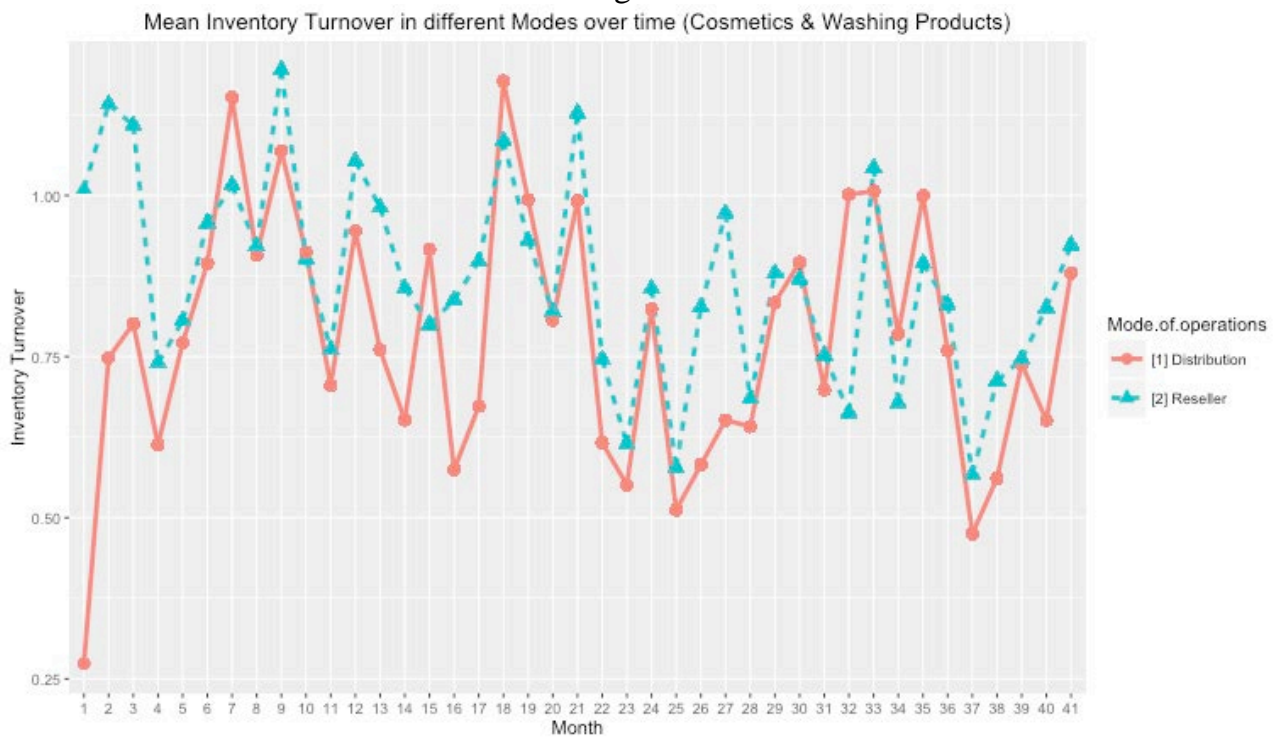




\section{Conclusion}

Distribution mode has been a prevalent retailing system in China. Under this system retailer transfer many decision power to manufacturer/supplier. Distribution mode is a possible solution for all the channel conflicts that retailers and manufacturers are facing now a day.

We studied the inventory turnover performance and prices under different retailing modes in different categories. We found that most of the categories in food and non-food section follow the literature rule and showed increase in inventory turnover for distribution mode while having low prices. But few categories defied this general rule and had higher inventory turnover even with higher prices in both reseller and distribution mode which may be due to the brand image and price insensitivity of these products.

To our best knowledge this has been the first empirical study that provides comparison between distribution and reseller mode in different categories belonging to food and non-food section. There have been many theoretical studies in marketing and operations research focusing on channel coordination and inventory management issues under several kinds of manufacturer-retailer contracts. We consider it essential from an academic perspective to empirically test the predictions generated from different theories. We also believe that our findings have managerial implications. Managers can use these findings to better manage their categories under different mode of operations.

There are few notable limitations in this study that can be addressed in future research using more detailed datasets from multiple retailers. The first limitation is the lack of variables that can subset a category products in different levels based on brands, product variety and sub-categories. Which can help us to understand the reason behind higher prices and higher inventory turnover in certain categories. Also it will shed light on why certain categories are more inclined towards one mode of operations than the other.

A second limitation of our study is that variables are measured at an aggregate level per month. So we cannot study the variation in inventory turnover on daily basis, which will be more accurate than the monthly or yearly one. Furthermore aggregate data limit us from seeing the effect of promotion on inventory turnover performance in different modes.

Our paper identifies opportunities for future research on mode of operations. One valuable area of research will be to investigate which categories in retailing are inclined towards which mode of operations and the reason behind that preference and to study the effect of other managerial metrics between different modes of operation. 


\section{References:}

1. Abhishek, V., Jerath, K., \& Zhang, Z. J. (2015). Agency selling or reselling? Channel structures in electronic retailing. Management Science.

2. Alan, Y., Gaur, V., \& Gao, G. (2011). Does inventory turnover predict future stock returns. Working paper, Cornell University, Ithaca, NY.

3. Cachon, G. P. 2003.Supply chain coordination with contracts. de Kok A. G., S. C. Graves, eds. Supply Chain Management: Design, Coordination and Operation. Elsevier Science, Amsterdam, NorthHolland, 229-339.

4. Cachon, G. P., M. A. Lariviere. 2005. Supply chain coordination with revenue-sharing contracts: Strengths and limitations. Management Sci. 51(1): 30-44.

5. Dong, Y., M. Dresner, Y. Yao. 2014. Beyond information sharing: An empirical analysis of vendor-managerd inventory. Prod. Oper. Manag. 23(5): 817-828.

6. Fisher, M. L., A. Raman, and A. McClelland. 2000. Rocket Science Retailing is Almost Here - Are You Ready? Harvard Business Review, July/August.

7. Gaur, V., Fisher, M. L., \& Raman, A. (2005). An econometric analysis of inventory turnover performance in retail services. Management science, 51(2), 181-194.

8. Gaur, V., Kesavan, S., \& Raman, A. (2014). Retail Inventory. California Management Review, 56(2), 55-76.

9. Hendricks, K. B., V. R. Singhal. 2001. The Long-run Stock Price Performance of Firms with Effective TQM Programs as Proxied by Quality Award Winners. Management Science, 47, 359-368.

10. Jerath, K., Z. J. Zhang. 2010. Store-within-a-store. J. Mark. Res. 47(4): 748-763.

11. Kurtulus, M., R. C. Savaskan. 2013.Drivers and implications of direct-store-delivery in distribution channel. Working paper, Owen Graduate School of Management, Vanderbilt University.

12. Kurtulus, M., A. Nakkas, S. Ulku. 2014. The value of category captainship in the presence of manufacturer competition. Prod. Oper. Manag. 23(3): 420-430.

13. Li, J., Chan, T. Y., \& Lewis, M. (2016). What Happens When Manufacturers Perform The Retailing Functions?. Production and Operations Management.

14. McGahan, A. M., M. E. Porter. 1997. How much does industry matter, really? Strategic Management Journal, 18, 15-30. 